\title{
Natural disaster, catastrophe and environmental protection in Vietnam
}

\author{
Thiên tai, thảm họa và bảo vệ môi truờng tại Việt Nam \\ Editorial
}

Chu, Thi Thu Ha*

Institute of Ecology and Biological Resources, Vietnam Academy of Science and Technology, 18 Hoang Quoc Viet, Cau Giay, Hanoi, Vietnam

\begin{abstract}
During development process, especially under the impact of climate change, natural disaster is one of the major challenges. In fact, the degree of devastation of natural disasters such as storms, floods and landslides are enormous, causing severe damage to people, property and environmental degradation. These natural disasters increasingly occurring more frequently in the last 20 years claimed the lives of many people. Unlike natural disasters, catastrophes are often related to human factors. Thus, the policy on response, treatment should also take into account the legal process in order to ensure that the principle of the polluter must bear responsibility after incidents and catastrophes. The catastrophe is a serious disruption of a community activity, causing loss of life, environment and material on a large scale. Normally catastrophe is beyond the capacity of affected communities to cope with, if only sources power of that community is used. The impact of economic - social development, climate change and natural disasters, environmental pollution situation, the capacity to respond to environmental incidents ... has been the pressure and challenge to Vietnam.
\end{abstract}

Trong quá trình phát triển, đặc biệt dưới tác động của biến đổi khi hậu, thiên tai là một trong nhũng thách thức lớn. Trong thực tế, mức độ tàn phá của thiên tai nhu bão, lũ và sạt lở đất là rất lớn, gây thiệt hại nặng nề về người, tài sản và gây suy thoái môi truờng. Nhũng thảm họa do thiên tai gây ra đang ngày càng xảy ra thường xuyên hơn trong 20 năm qua, cướp đi sinh mạng của nhiều người. Khác với thiên tai, thảm họa môi truờng thuoòng liên quan đến yếu tố con người. Do đó, chính sách ưng phó, xử lý cũng cần tính đến các quá trình pháp lý nhằm đảm bảo nguyên tắc nguời gây ô nhiếm phải chịu trách nhiệm sau sự cố, thảm họa. Thảm họa là sụ phá võ̃ nghiêm trọng hoạt động của một cộng đồng, gây ra nhüng tổn thất về người, môi truòng, vật chất trên diện rộng. Thảm họa thường vuợt quá khả năng đối phó của cộng đồng bị ảnh huơơng nếu chỉ sủ dụng các nguồn lục của cộng đồng đó. Tác động của sự phát triển kinh tế - xã hội, biến đổi khi hậu và thiên tai, thực trạng ô nhiễm môi truờng, năng lực ưng phó với sụ cố môi trường... đã và đang là nhũng áp lục và thách thức không nhỏ với Việt Nam.

Keywords: natural disaster, catastrophe, environmental pollution

\section{Introduction}

Environmental issue in Vietnam is attracting the interest of many stakeholders. Recently, the serious phenomenon of dead fish in the South Sea, drought in Central, high tides flooding in the South of Vietnam, etc is the problem that has no effective solution at this moment. Thus, the contributing of scientists from the various specialized fields, in collaboration with functional departments and government is essential to overcome and find viable options to address.
In the period 2011-2015, natural disasters occurred in Vietnam, although few in number, but the intensity of the impact was very high such as intense heat with high temperature base and extended in huge area, unusually heavy rain in many localities, landslides, salinisation and exhaustion of water sources, etc. Especially, in 2015 many extreme weather phenomena, such as unusually cold weather and snow in the north, unseasonal heavy rain, thunderstorm, hail and tornado that occurred in many localities. The response to the reversal phenomenal was often ineffective that caused major consequences for people and the economy (Ministry of Natural Resources and Environment, 2015). 
Under the impact of climate change and economic - social development activities, the situation of natural disaster in Vietnam is increasingly complicated. Environmental impact has caused many problems to public health such as getting diseases related to water pollution and lack of clean water. Environmental pollution is causing environmental conflicts, including conflicts of industrial production, trade villages, landfills, agriculture, hydropower development and mining.

\section{Natural disaster, catastrophe and consequence}

The number of storms and floods recorded are increasing, while droughts, heat waves and extreme cold have similar direction. In 2014, the most severe drought in recent 40 years made depletion of water resources, increased area of wasteland in the arid and semi-arid regions. Besides, land salinization, acidification spread in the Mekong Delta region and some provinces in the North. Environment after storms, floods were severely degraded, typically surface water pollution increased disease or environmental degradation due to soil erosion, landslides, etc.

Water floods, flash floods dissolved much dirt accumulated during the dry season or the waste, hazardous substances from the sites of collecting, gathering and processing solid waste, from wastewater treatment facilities, wastewater drainage systems that were destroyed, and from the storage of chemicals, storage of plant protection products, etc. caused surface water in areas of storm and flood to contain high levels of pathogenic microorganisms, highly toxic chemicals to the environment, etc. have the ability to spread over large areas.

Under the impact of temperature and habitat changes due to environmental pollution, lack of hygienic living conditions after the natural disaster caused the diseases such as malaria, dengue fever (by mosquitoes), encephalitis, through the aquatic environment (intestinal disease) and other diseases (malnutrition, lung diseases, etc.) to occur more frequently.

Heavy rain, flash floods also increased erosion, soil runoff, flooding, landslides and soil erosion leading to soil degradation. The environmental degradation of land led to the degradation of fauna and flora and the decline of agricultural land per capita.

Waste pollution caused mass death of fish, killed hundreds of coastal lobster cages, tons of fish in ponds, rivers and sea. Especially in 2016, the phenomenon of mass death of fish in the Eastern Sea at Central Vietnam was catastrophe causing damage to thousands of fishermen and potentially toxic risk for human when they use polluted marine resources. Dealing with the consequences of the disaster is a difficult problem that not every country can process.

Vietnam had strategies for preventing and mitigating natural disasters through 2020 (Government of Vietnam, 2007), but could not avoid the loss caused by natural disasters. Facing to the disaster damage, a number of measures to adapt to natural disasters such as seasonal changes, selec- tion of appropriate breeding animals and plants; restrictions as well as take advantage of the positive effects (such as abundant amount of alluvium, seafood after the flood season). However, these measures are so far not properly interested in and invested to research, the consequence is that people still suffer damage annually by natural disasters.

\section{Environmental protection}

The socio-economic development is now pressure on the environment. The process of urbanization, population and growth of traffic, industrial parks, economic zones, agriculture, marine economy, the industry caused a negative impact to the environment, natural resources and ecological imbalance. In the 5-year period from 2011 to 2015, environmental protection existed problems, in particular faced many pressing issues that need to be focused to resolve. Mining activities in many localities lacking management increased the hot spots of pollution. Waste from agricultural production and daily life of people in rural areas were not collected and treated properly. The use of chemical fertilizers, plant protection products led to pollution in rural areas on a large scale and increasing level. Toxic substances leaching into the water, soil, vegetation affected human health, in the long term the damage is not measurable. Many craft village activities are also causing high pollution for environment like heavy metal pollution (Chu Thi Thu Ha, 2011). Drought and desertification due to the impacts of extreme weather and climate change is becoming increasingly serious. In particular, marine environmental issues and other environmental incidents in recent years has caused huge economic, social and environmental consequences.

Solid waste pollution continued to be a key environmental issue. Nationally, solid waste increased up to $10 \%$ per year, of which $46 \%$ was generated from urban living, $17 \%$ was generated from industrial production, the rest was generated from the countryside, craft villages and pubic health. However, the collection, treatment were still low, at around 40\%. Management, investment for technology processing solid waste have not had much improved compared to the previous period (Ministry of Natural Resources and Environment, 2015).

At 4 fields of environment: surface water, ground water, soil and atmosphere, in recent 5 years, the pollution in each field also had certain increase that needs more urgent solutions. For example, the decline in soil quality tends to increase in both size and extent by the negative impact of climate change and the activities of economic - social development.

Vietnam is facing serious challenges between environmental protection, natural resources and economic development. There are a lot of problems. The forests have been devastated mercilessly. Deforestation is the loss of green vegetation, timber resources, biological resources, ecology balance and biodiversity. Forest loss is the loss of water sources, land, causing erosion, desertification or floods, landslides in several provinces for many years. 
Many cancer villages in several provinces appeared by toxic waste, heavy metals, pesticide residues emiited from plants, factories. This situation exist in almost localities in Vietnam with the level of contamination risk is huge and widespread. Facing this situation, it is needed the attention from the Government to save the environment in Vietnam.

\section{DAAD alumni workshop on "Envi- ronment and Natural Resources"}

Strengthening, renewing dissemination and education to improve people's awareness about the environment and natural resources protection are very necessary. The studies on the state of the environment, pollution treatment solutions, biodiversity and conservation of animals plants, water resource management, development of renewable energy and bio-energy in particular are really essential for a cleaner environment, keeping the ecological balance and slowing down climate change. DAAD Alumni workshop: "Environment and Natural Resources" is an opportunity for scientists and lecturers in Vietnam and in Germany to discuss together and present research achievements on environment and natural resources with about 50 papers.

The content of the workshop will contribute to convey a meaningful message about environmental protection, conservation of biodiversity, adaptation to climate change, promotion of research activities for the environment and resources natural.

This will be an opportunity for Vietnamese and German scientists to share experiences and solution to improve the quality and effectiveness of management of environment and natural resources. An important expectation is through this workshop, Vietnamese scientists who graduated in Germany with high academic qualifications to establish collaborative relationships with scientists working in Germany for proposing joining scientific research projects.

\section{References}

[1] Ministry of Natural Resources and Environment (2015) National state of environment report in the period 2011-2015, $244 \mathrm{pp}$.

[2] Chu Thi Thu Ha (2011) Survey on heavy metals contaminated soils in Thai Nguyen and Hung Yen provinces in Northern Vietnam. Journal of Vietnamese Environment, Vol.1, No.1, 34-39.

[3] Government of Vietnam (2007) Decree number 172/2007/QĐ-TTg date 16/11/2007 of Vietnam Prime Minister on Approving the national strategy for prevention and mitigation of natural disasters through 2020 . 